\title{
IAMJ
}

INTERNATIONAL

AYURVEDIC

MEDICAL JOURNAL

\section{A RANDOMISED CONTROLLED CLINICAL TRIAL TO STUDY THE EFFICACY OF SATYADI CHURNA AND VYAGHRI CHURNA IN TAMAKA SWASA}

\author{
$\underline{\text { Anagha Narayanan }}{ }^{1}, \underline{\text { Susheel Shetty }}^{2}$ \\ ${ }^{1}$ III ${ }^{\text {rd }}$ Year P.G. Scholar, ${ }^{2}$ Guide, Professor and HOD \\ Dept of P.G. Studies in Kayachikitsa, Alva's Ayurveda Medical College Moodbidri, Dakshina Kannada, \\ Karnataka, India
}

Corresponding Author: anunavarang4@gmail.com

https://doi.org/10.46607/iamj1209092021

(Published Online: September 2021)

Open Access

(C) International Ayurvedic Medical Journal, India 2021

Article Received: 29/08//2021 - Peer Reviewed: 06/09/2021 - Accepted for Publication: 07/09/2021

Check for updates

\section{ABSTRACT}

Background and Objectives: Tamaka Swasa is a form of Swasa Roga primarily affecting the Pranavaha Srotas characterized by Swasakrichratha, Ghurghuraka, Teevra vega Swasa etc. Tamaka Swasa in Ayurvedic classics appears to be similar to Bronchial Asthma. Several medications are available in today's medical system to treat this disease, but they are known to cause a variety of side effects. Hence, the suffering population is turning to conventional remedies for better relief. In this regard, Ayurveda can provide promising results in Tamaka Swasa with varieties of treatment modalities. In light of these considerations, the aim of the study was to assess the efficacy of two Ayurvedic formulations Satyadi Churna listed in Swasakarmavipaka adhyaya in Brihat Nighantu Ratnakara and Vyaghri Churna mentioned in Curnakalpana Adhyaya in Sharangdhara Samhita in the treatment of mild to moderate Bronchial Asthma.

Materials and Methods: 40 Tamaka Swasa Subjects were selected those fulfilling the diagnostic and inclusion criteria. They were randomly assigned into two equal groups. Comparative analysis of the overall effect of the treatments in both the Groups was done statistically with Mann- Whitney Rank Sum Test and within the Group comparison with Wilcoxon Signed Rank Test. Results: Within the group comparison showed statistically significant results for all the criteria in Group A while in Group B except Peenasa all other criteria showed statistically significant results. Conclusion: When comparing both groups Satyadi Churna showed better 
improvement in the symptoms of Tamaka Swasa than Vyaghri Churna. Hence H1 holds good and proved.

Keywords: Tamaka Swasa, Bronchial Asthma, Satyadi Churna, Vyaghri Churna, Peak flow meter.

\section{INTRODUCTION}

Tamaka Swasa is one of the five types of Swasa Roga mentioned in Ayurvedic classics. Acharyas have mentioned the lakshana of Tamaka Swasa as Teevravega Swasa (deep velocity breathing), Ghurghuraka (wheezing), Kasa (cough) etc. ${ }^{1}$ The etiopathogenesis, signs and symptoms of Bronchial Asthma explained in modern science are comparable with the disease entity Tamaka Swasa. In the present scenario, due to growing environmental pollution with rapid industrialization, the incidence of Bronchial Asthma has posed a serious problem. It is reported that, in India, subjects suffering from Bronchial Asthma is estimated to be more than 17-30 million ${ }^{2}$. It is the main reason for global morbidity and occurs because of the weakening of the immune system in response to exposure to allergens or environmental exposure, an unmet need in modern science is the development of effective oral therapy for mild and moderate asthma without any side effects. Thus, studies are needed to be carried out in this disease to find out a better remedy with no or least side effects. Also, asthma subjects who do not respond to marketed antiasthmatic drugs needed novel biological medications to regulate the asthmatic situation. While explaining the treatment of Swasa Roga, Acharyas have mentioned the importance of Shamana and Brimhana Chikitsa over Shodana Chikitsa. Shamana Chikitsa is applicable for all age groups and even in subjects of mild and moderate strength and it can also be done on an OP basis.

Considering all these aspects, the study was framed to evaluate the efficacy of two Ayurvedic formulations namely Satyadi Churna ${ }^{3}$ mentioned in Swasakarmavipaka adhyaya in Brihat Nighantu Ratnakara and Vyaghri churna ${ }^{4}$ mentioned in Curnakalpana Adhyaya in Sharangdhara Samhita.

MATERIAL AND METHODS OBJECTIVES OF THE STUDY:

1. To evaluate the efficacy of Satyadi Churna in the treatment of Tamaka Swasa.

2. To evaluate the efficacy of Vyaghri Churna in the treatment of Tamaka Swasa.

3. To compare the efficacy of Satyadi Churna and Vyaghri Churna in the treatment of

Tamaka Swasa.

\section{SOURCE OF DATA}

\section{LITERARY SOURCE:}

All the Ayurvedic, modern literature and contemporary texts including the journals and websites were reviewed and documented about the disease and drug for the study.

\section{PHARMACEUTICAL SOURCE:}

The formulation selected for this work, Satyadi Churna and Vyaghri Churna were prepared in the Alva's Pharmacy, Mijar as per the literature reference. Raw drugs were purchased from the authenticated Ayurvedic dealer duly identified by the experts.

\section{CLINICAL SOURCE:}

Subjects diagnosed with Tamaka Swasa with mild and moderate signs and symptoms were selected from

- The outpatient department and Inpatient Department of Post Graduate studies in Kayachikitsa of Alva's Ayurveda Medical College Hospital.

- Medical camps and other referrals.

\section{METHOD OF COLLECTION OF DATA}

\section{a. SAMPLE SIZE:}

A minimum of 40 subjects irrespective of gender, caste, religion, socioeconomic status and those fulfilling the diagnostic and inclusion criteria were selected. They were randomly assigned into two equal groups (group A and group B).

STUDY DESIGN: Parallel group comparative clinical study

BLINDING: Single-blind

METHOD OF SAMPLING: Lottery method 


\section{b. PLAN OF STUDY. Group A (Trial drug)}

Sample size: 20 subjects

Drug: Satyadi Churna

Dose: $1 / 2$ teaspoon with 2 hours gap for 6 times Anupana: Madhu

Duration: 14 days

\section{Group B (Standard drug)}

Sample size: 20 subjects

Drug: Vyaghri Churna

Dose: $1 / 2$ teaspoon with 2 hours gap for 6 times

Anupana: Madhu

Duration: 14 days

\section{OBSERVATION PERIOD:}

- Subjects were observed on the 0th day, 8th day and 15th day of treatment to assess the progress.

- Follow up assessment was done after 2 weeks.

- Total study duration including follows up: 28 days.

\section{DIAGNOSTIC CRITERIA:}

The patient was diagnosed based on,

- Swasa Krichratha (Difficulty in breathing)

- Ghurghuraka (Audible and or auscultatory wheezing)

- Urah peedah (Chest tightness)

- With or without Kapha nishteevana (Expectoration of sputum), Peenasa (Rhinitis), Kasa (Cough)

- Global Initiative for Asthma (GINA) diagnostic criteria

- Peak Expiratory Flow Rate between 80 - 300 $\mathrm{Lit} / \mathrm{min}$

\section{INCLUSION CRITERIA}

- Subjects between 16-70 yrs. of age fulfilling the diagnostic criteria

- Subjects with mild and moderate symptoms of Tamaka Swasa

- Subjects willing to participate in the study.

- Previously treated cases of Bronchial Asthma with no active medication.
- Fresh cases of Bronchial Asthma.

EXCLUSION CRITERIA:

- Bronchial asthma having a severe attack who requires oxygen and nebulization support.

- Subjects with other systemic disorders which may interfere with the course of the study.

- Lung carcinoma and other lung pathology.

- Other complicated respiratory disorders like COPD, TB, Pneumonia, etc.

- Subjects addicted to smoking

- Subjects under steroidal therapy

- Pregnant and lactating women

ASSESSMENT CRITERIA: SUBJECTIVE PARAMETERS:

Grading as mild and moderate was done considering cardinal features of Tamaka Swasa and assessment of the condition was made based on detailed case proforma.

- Swasa Krichratha

- Ghurghuraka

- Ura peeda

- Kasa

- Peenasa

- Kapha nishteevana

\section{OBJECTIVE PARAMETERS:}

Peak expiratory flow rate (before and after an interventional period and after follow up)

\section{INVESTIGATIONS:}

Routine Haematological tests and Chest X-Ray of PA and lateral views were carried out whenever found necessary.

The assessment was done by adopting standard scoring methods by subjective and objective parameters and was analysed statistically.

\section{STATISTICAL TEST:}

Comparative analysis of the overall effect of the treatments in both the groups was done statistically with Mann-Whitney Rank Sum Test and within the group comparison with Wilcoxon Signed Rank Test. 


\section{RESULTS}

Table 1: Effect of Satyadi Churna in Subjective and Objective Parameters in Group A

\begin{tabular}{|l|l|l|l|l|l|l|l|l|}
\hline CRITERIA & MEAN BT & MEAN AT & M.D & $\%$ & S.D & S.E & WSRT VALUE & p VALUE \\
\hline SWASAKRICHRATA & 2.00 & 0.25 & 1.75 & 87.50 & 0.444 & 0.102 & 210.00 & $<0.001$ \\
\hline GHURGHURAKA & 1.80 & 0.15 & 1.65 & 91.67 & 0.489 & 0.112 & 210.00 & $<0.001$ \\
\hline URA PEEDA & 2.00 & 0.30 & 1.70 & 85.00 & 0.470 & 0.108 & 210.00 & $<0.001$ \\
\hline PEENASA & 0.65 & 0.10 & 0.55 & 84.62 & 0.887 & 0.204 & 21.00 & $<0.05$ \\
\hline KAPHA NISHTEEVANA & 2.2 & 0.60 & 1.60 & 72.73 & 0.754 & 0.173 & 171.00 & $<0.001$ \\
\hline KASA & 0.80 & 0.20 & 0.60 & 75.00 & 0.821 & 0.188 & 36.00 & $<0.01$ \\
\hline PEFR & 0.95 & 0.20 & 0.75 & 78.95 & 0.444 & 0.102 & 120.00 & $<0.001$ \\
\hline
\end{tabular}

Table 2: Effect of Vyaghri Churna in Subjective and Objective Parameters in Group B

\begin{tabular}{|l|l|l|l|l|l|l|l|l|}
\hline CRITERIA & MEAN BT & MEAN AT & M.D & \% & S.D & S.E & WSRT VALUE & p VALUE \\
\hline SWASAKRICHRATA & 1.80 & 0.45 & 1.35 & 75.00 & 0.671 & 0.154 & 171.00 & $<0.001$ \\
\hline GHURGHURAKA & 1.85 & 0.40 & 1.45 & 78.38 & 0.510 & 0.117 & 0.117 & $<0.001$ \\
\hline URA PEEDA & 1.45 & 0.30 & 1.15 & 79.31 & 0.489 & 0.112 & 0.112 & $<0.001$ \\
\hline PEENASA & 0.35 & 0.10 & 0.25 & 71.43 & 0.444 & 0.102 & 0.102 & $>0.05$ \\
\hline KAPHA NISHTEEVANA & 1.15 & 0.25 & 0.90 & 78.26 & 0.852 & 0.196 & 0.196 & $<0.001$ \\
\hline KASA & 0.55 & 0.15 & 0.40 & 72.73 & 0.681 & 0.156 & 0.156 & $<0.05$ \\
\hline PEFR & 0.90 & 0.20 & 0.70 & 77.78 & 0.470 & 0.108 & 0.108 & $<0.001$ \\
\hline
\end{tabular}

Table 3: Comparative effect of Group A and Group B

\begin{tabular}{|l|l|l|l|l|}
\hline \multirow{2}{*}{ CRITERIA } & \multicolumn{2}{l|}{ MEAN DIFFERENCE } & \multicolumn{2}{l|}{ ney Rank Sum Test } \\
\cline { 2 - 5 } & GROUP A & GROUP B & T VALUE & pVALUE \\
\hline SWASAKRICHRATA & 2.000 & 1.000 & 475.00 & $>0.05$ \\
\hline GHURGHURAKA & 2.000 & 1.000 & 433.500 & $>0.05$ \\
\hline URA PEEDA & 2.000 & 1.000 & 531.00 & $<0.01$ \\
\hline PEENASA & 0.000 & 0.000 & 432.500 & $>0.05$ \\
\hline KAPHA NISHTEEVANA & 2.000 & 1.000 & 497.500 & $<0.01$ \\
\hline KASA & 0.000 & 0.000 & 434.000 & $>0.05$ \\
\hline PEFR & 1.000 & 1.000 & 440.000 & $>0.05$ \\
\hline
\end{tabular}

Table 4: Overall effect of group A

\begin{tabular}{|l|l|l|}
\hline EFFECT OF TREATMENT IN & GROUP $-\mathbf{A}$ & No of subjects \\
\hline Class & Grading & 0 \\
\hline $0 \%$ & No improvement & 0 \\
\hline $1-25 \%$ & Mild improvement & 0 \\
\hline $26-50 \%$ & Moderate improvement & 3 \\
\hline $51-75 \%$ & Marked improvement & 10 \\
\hline $76-99 \%$ & Significant Improvement & 7 \\
\hline $100 \%$ & Complete Relief & \\
\hline
\end{tabular}


Table 5: Overall effect of Group-B

\begin{tabular}{|l|l|l|}
\hline EFFECT OF TREATMENT IN & GROUP - B & \\
\hline Class & Grading & No of subjects \\
\hline $0 \%$ & No improvement & 0 \\
\hline $1-25 \%$ & Mild improvement & 0 \\
\hline $26-50 \%$ & Moderate improvement & 3 \\
\hline $51-75 \%$ & Marked improvement & 12 \\
\hline $76-99 \%$ & Significant Improvement & 2 \\
\hline $100 \%$ & Complete Relief & 3 \\
\hline
\end{tabular}

\section{DISCUSSION}

This study was an attempt to evaluate the efficacy of Satyadi Churna and Vyaghri Churna and it has found out that Satyadi Churna was effective in reducing the attack of Tamaka Swasa and helped in increasing PEFR of studied cases and found statistically highly significant results at $\mathrm{p}<0.001$

Due to the Ruksha, Teekshna, Ushna gunas of the drugs, the drug mixture in Satyadi Churna works on the vitiated Vata and Kapha dosha, performing Kapha Vilayana, Lekhana, Kapha Nirharana and Vata Shamana. The drug's Deepana and Pachana actions aid in the digestion of Ama and stabilize Agni. Its Lekhana action aids in the clearing of obstructed Sroto marga caused by vitiated Kapha. Owing to the unique acts of drugs like Shwasahara, Kasahara, and Shothahara, these symptoms have been alleviated.

Satyadi Churna also functions as a Rasayana, providing power to the Pranavahasrotas and acting as an immunomodulator by improving immunity. The drug's Shothahara action has helped to minimise airway inflammation. Bronchial asthma is a chronic inflammatory disorder and mast cells, eosinophils, and T- lymphocytes play an important role. The ingredients in Satyadi Churna may be collectively effective on airflow obstruction and airway hyperresponsiveness by the drugs bronchodilator, antiallergic, anti-inflammatory, antihistaminic, immunomodulatory, mucolytic, and expectorant actions.

The most widely used adjuvant in respiratory diseases is Madhu, which is provided as the Anupana in the study. It is Tridoshahara and has properties such as Lekhana, Chedhana, Deepana, Yogavahi, and so on. For these reasons, it improves the churn's properties, especially due to its Yogavahi guna. It causes Kapha Vilayana and Kapha Visravana due to its Chedhana and Lekhana properties.

The verdict of the whole analysis is the conclusion. The following findings are taken from the present study regarding Tamaka swasa and its management.

\section{CONCLUSION}

The key causes of Tamaka Swasa are found to be a change in diet, increased stress, pollution, and cold weather.

The condition Tamaka swasa can be equated with Bronchial Asthma in modern parlance due to its similarity in presentation.

When comparing the two drugs, both Satyadi Churna and Vyaghri Churna have major effects on Tamaka Swasa symptoms. Percentage improvement in Swasakrichratha, Ghurghuraka, Ura peeda, Peenasa, Kasa as well as the objective criteria PEFR was more in Satyadi Churna than Vyaghri Churna.

Within the group, the comparison showed statistically significant results for all the criteria in Group A, while in Group B except Peenasa all other criteria showed statistically significant results.

Between the groups, the comparison showed Statistically significant results in Swasakrichrata (BT-AFU), Ghurghuraka (BT-AT1) Ura Peeda and Kapha Nishteevana.

As a result, $\mathbf{H 1}$ is true and has been proven, which means there is a significant difference in the effect of Satyadi Churna and Vyaghri Churna in the symptomatic management of Tamaka Swasa.

During the clinical trials, neither drug produced any side effects, and almost all the drugs in this study had the properties needed to break down Tamaka Swasa 
Samprapti. Kaphavata Hara, Deepana, Pachana, Anulomana, Srotoshodhana, Antiasthmatic, and Antiinflammatory properties are all present in both drugs.

\section{REFERENCES}

1. Dr Ram Karan Sharma, Dr Vaidya Bhagwan Dash, Charaka Samhitha with English translation, edition reprint 2012, Varanasi, Chaukhamba Sanskrit Series Office; Vol IV, Chikitsa Sthana, Chapter 17, Sloka no 46-68, Pg 128-134.

2. Dr Behera, Inderpaul Singh Sehgal. Bronchial asthma-Issues for the developing world. The Indian Journal Of Medical Research 2015;141(4):. http://www.ijmr.org.in/article.asp. [ cited on 22/02/2019].

3. Shri Dhattarama Srikrishnalala Mathura, Brihath Nighantu Ratnakar with Hindi commentary,1996, Bombay, published by Khemaraja Srikrishnadasa Prakashana; Vol 5-6, Chapter 10, Pg no 284.

4. Acharya Sarangadhara. Sarangadhara Samhitha, with English translation by Dr Himasagara Chandra Murty, Varanasi, Chaukhamba Sanskrit Series Office; second edition 2007, Madhyama Khanda, Chapter 6, Sloka no 147, Pg 174.

5. Balmes J, Becklake M, Blanc P, Henneberger $\mathrm{P}$, Kreiss K, Mapp C, et al. American thoracic society statement: occupational contribution to the burden of airway disease. Am J Respir Crit Care Med. (2003) 167:787-97. DOI: $10.1164 / \mathrm{rccm} .167 .5 .787$

6. Newcomb et al. Testosterone attenuate group 2 innate lymphoid cell-mediated airway inflammation. Cell Reports, 2017 DOI: 10.1016/j.celrep.2017.10.110.

7. Acharya Y T. Sushruta Samhita with Nibandhasangraha commentary of Dalhanacharya. Sutra sthana 21/23. Reprint ed. Varanasi (India): Chaukambha Sanskrit Sansthan; 2010. p. 196

8. https://www.researchgate.net/publication/329439962 _Work-

Related_Symptoms_of_Patients_with_Asthma_A_M ulticenter_Study.

9. Hancox RJ, Milne BJ, Taylor DR, et alRelationship between socioeconomic status and asthma: a longitudinal cohort study hoax 2004;59:376-380

10. Janson C, Gislason T, Boman G, Hetta J, Roos BE. Sleep disturbances in patients with asthma. Respir Med. 1990 Jan;84(1):37-42. doi: 10.1016/s09546111(08)80092-3. PMID: 2371419.

11. Bukowskyj M, Nakatsu K. The bronchodilator effect of caffeine in adult asthmatics. American Review of Respiratory Disease 1987;135(1):173-5. [PubMed] [Google Scholar]

12. Acharya $\mathrm{Y}$ T. Sushruta Samhita with Nibandhasangraha commentary of Dalhanacharya. Sutra sthana 21/23. Reprint ed. Varanasi (India): Chaukambha Sanskrit Sansthan; 2010. p. 196

13. Papi A, Canonica GW, Maestrelli P, Paggiaro P, Olivieri D, Pozzi E, et al. Rescue use of beclomethasone and albuterol in a single inhaler for mild asthma. N Engl J Med. 2007;356:2040-2052. [PubMed] [Google Scholar].

14. Acharya Y T. Sushruta Samhita with Nibandhasangraha commentary of Dalhanacharya. Chikitsa sthana 33/22. Reprint ed. Varanasi (India): Chaukambha Sanskrit Sansthan; 2010. p. 312

15. Acharya Yadavji Trikamji(editor), Agnivesha, Charaka samhita, Chaukhamba Sanskrit Sansthan, Varanasi, Reprint 2000 page 279-280.

16. Charaka Samhita, Shastri K, Chaturvedi G., editors. Varanasi: Chaukhamba Bharti Academy; 2004. p. 461. [Google Scholar]

17. Paradakara HS, Astanga Hridaya Sharirasthana 3/84, Chaukhambha Orientalia Varanasi Reprint edition, 2011, P; 402.

18. Acharya YT. Charaka Samhita with Ayurveda Dipika commentary of Chakrapani Datta. Sutra Sthana 1/44. Reprint ed. Varanasi (India): Chaukambha Orientalia

\section{Source of Support: Nil Conflict of Interest: None Declared}

How to cite this URL: Anagha Narayanan \& Susheel Shetty: A Randomised Controlled Clinical Trial To Study The Efficacy Of Satyadi Churna And Vyaghri Churna In Tamaka Swasa. International Ayurvedic Medical Journal \{online\} 2021 \{cited September 2021\} Available from: http://www.iamj.in/posts/images/upload/2006_2011.pdf 